\title{
KARATERISTIK PENYAKIT TELINGA LUAR DI MAKASSAR SULAWESI SELATAN
}

Utami Murti Pratiwi

Bagian Biomedik Fakultas Kdokteran dan Ilmu Kesehatan, Universitas Islam Negeri

Alauddin Makassar

+628118811355

E-mail: utami.murti@uin-alauddin.ac.id

Syahrijuita

Bagian Ilmu Penyakit Telinga Hidung dan Tenggorokan, Fakultas Kedokteran, Universitas

Hasanuddin Makassar

$+628124180227$

Sri Ramadhany

Bagian Ilmu Kesehatan Masyarakat Fakultas Kedokteran Universitas Hasanuddin

Makassar

$+62885242184000$

E-mail: sriharun@live.com

\begin{abstract}
Abstrak
Di Indonesia, kehilangan pendengaran dan ketulian masih merupakan salah satu masalah yang dihadapi masyarakat oleh karena kurangnya infrastruktur, kurangnya kesadaran dan pengetahuan publik tentang kesehatan indera pendengaran untuk mencegah penyakit tersebut. Penelitian deskriptif ini bertujuan untuk memperoleh data karakteristik penyakit telinga luar di klinik THT RSWS periode Januari-Desember 2012. Jenis penelitian ini adalah penelitian epidemiologi deskriptif dengan menggunakan data sekunder yang diperoleh dari rekam medis. Jumlah pasien dengan penyakit telinga luar dalam penelitian ini adalah 984 kasus. Hasil penelitian menunjukkan bahwa persentase tertinggi ditemukan pada kelompok usia> 50 tahun $(21,7 \%)$ dan proporsi pasien lebih banyak pada laki-laki $(50,2 \%)$ dibandingkan wanita (49,8\%). Berdasarkan jenisnya, otitis eksterna merupakan jenis yang terbanyak yaitu 408 kasus (43,2\%). Distribusi penyakit otitis eksterna berdasarkan jenis kelamin dan umur, diperoleh bahwa perempuan lebih banyak menderita otitiss eksterna dibandingkan laki-laki, sedangkan kelompok umur yang terbanyak adalah kelompok umur lebih dari 50 tahun diikuti dengan kelompok umur 0-10 tahun dengan jenis penyakit yang terbanyak adalah otitis eksterna difus profunda yaitu 24 kasus $(57,4 \%)$. Sehingga dapat diambil kesimpulan bahwa penyakit telinga luar secara umum lebih banyak ditemukan pada laki-laki dengan usia lebih dari 50 tahun. Sedangkan untuk jenis penyakit telinga luar yang paling banyak diderita adalah jenis otitis eksterna.
\end{abstract}

Kata kunci: otitis eksterna, penyakit telinga eksternal, cerumen obturans, hematoma aurikularis

\section{PENDAHULUAN}

Gangguan telinga merupakan masalah penting di negara-negara Asia Tenggara, termasuk di Indonesia. Kehilangan pendengaran dan ketulian masih merupakan masalah yang dihadapi masyarakat ${ }^{1}$. Penyakit telinga eksternal seperti otitis eksterna adalah penyakit dari penyakit telinga eksternal yang paling sering ditemukan ${ }^{2}$. Saluran pendengaran eksternal (juga disebut saluran telinga atau saluran telinga eksternal) adalah struktur kartilago berbentuk $S$ yang melintasi saluran medial menuju gendang telinga. Ini memanjang dari daun telinga ke membran timpani. Lesi kongenital, inflamasi, neoplastik, dan traumatik dapat mempengaruhi external auditory canal $(\mathrm{EAC})^{3}$. 
Telinga luar terdiri dari telinga dan saluran telinga ke membran timpani. Tulang rawan telinga terdiri dari elastin dan kulit. Sepertiga bagian luar dari kulit saluran telinga ada banyak kelenjar cerumen (dimodifikasi dengan kelenjar keringat atau kelenjar cerumen) dan rambut ${ }^{4}$. Penyumbatan cerumen prop adalah yang paling sering ditemukan pada anak-anak usia sekolah ${ }^{5}$. Cerumen telah menjadi penyebab utama konsultasi perawatan primer, dan komorbiditas umum pada pasien ${ }^{6}$. Kelainan telinga luar dibagi menjadi tiga, ada gangguan aurikularis, gangguan saluran telinga dan kelainan kongenital. Abnormalitas aurikular termasuk hematoma, pseudocysta dan perichondritis. Hematoma biasanya terjadi pada remaja atau orang dewasa yang memiliki aktivitas yang melibatkan kekerasan, itu hanya dapat ditemukan pada orang tua dan anak-anak. Tiga jenis kelainan aurikularis sebagian besar disebabkan oleh trauma dalam bentuk gigitan serangga untuk menyebabkan infeksi lain ${ }^{4}$.

Kelainan pada liang telinga dapat berupa cerumen, benda asing, otitis eksternal, otomikosis, herpes zoster oticus, keratosis obturans hingga infeksi kronis lainnya ${ }^{4}$. Hampir semua gangguan telinga tengah sering terjadi. Selain benda-benda asing, yang sering ditemukan pada anakanak yang dapat mempengaruhi gangguan pendengaran sehingga dapat mengganggu proses belajar di sekolah adalah otitis eksterna yang merupakan peradangan pada liang telinga akut disebabkan oleh infeksi oleh bakteri, jamur, dan virus juga sering terjadi di udara lembab dan kasus ini paling sering terjadi pada anak-anak ${ }^{4,5,7}$. Lebih lanjut, kolesteatoma adalah sejenis telinga luar yang prevalensinya juga sering ditemukan. Kolesteatoma kanal jarang terjadi pada patologi otologik, sering menyebabkan kesalahan diagnosis sebagai otitis atau otomikosis eksternal oleh dokter yang tidak terbiasa dengan penyakit ini ${ }^{8}$. Kelainan yang paling umum adalah telinga yang terlihat lebih lebar dan lebih mapan (telinga kelelawar), yang biasanya disertai dengan atresia microtia dan fistula pre auricular ear canal. Berbagai kelainan kongenital dari telinga eksternal yang disebabkan oleh gangguan perkembangan brachial arch pertama dan kedua ${ }^{4}$. Dengan meningkatnya masalah gangguan pendengaran dan ketulian di Indonesia, perlu untuk mengantisipasi perilaku promotif, perawatan kesehatan preventif serta memberikan indra pendengaran yang optimal sebagai upaya kuratif dan rehabilitatif kepada masyarakat. Oleh karena itu diperlukan kerja sama dan visi bersama dari berbagai pihak ${ }^{5}$. Melihat 
fakta bahwa gangguan telinga merupakan masalah penting di daerah Asia Tenggara, terutama di Indonesia, penelitian ini bertujuan untuk mengetahui informasi tentang karakteristik pasien penyakit telinga eksternal yang menjalani perawatan di telinga hidung dan tenggorokan.

\section{BAHAN DAN METODE}

Desain penelitian yang digunakan adalah studi epidemiologi deskriptif, data dikumpulkan sebagai data sekunder yang diperoleh dari rekam medis. Populasi penelitian adalah semua pasien yang telah diobati dengan diagnosis penyakit telinga eksternal di Klinik Telinga, Hidung dan Tenggorokan di Wahidin Sudirohusodo Rumah Sakit Umum Makassar pada periode Januari- Desember 2012. Sebagian besar populasi diambil sampelnya yaitu pasien rawat jalan. Pengambilan sampel dilakukan dengan total sampling. Instrumen yang digunakan dalam penelitian ini adalah kuesioner dengan beberapa tabel untuk mencatat data yang diperlukan dari rekam medis. Pengumpulan data telah dilakukan dalam bentuk data sekunder yang diperoleh dari dokumen-dokumen medis pasien penyakit telinga eksternal yang telah menjalani perawatan di klinik THT Wahidin Sudirohusodo Rumah Sakit Umum Makassar pada periode Januari hingga Desember 2012.
Kriteria yang termasuk dalam penelitian ini adalah pasien yang memiliki catatan medis. Sedangkan kriteria yang tidak dianalisis dalam penelitian ini adalah data yang tidak memiliki data lengkap tentang usia, jenis kelamin dan diagnosis penyakit. Penyakit telinga luar yang dimaksud dalam penelitian ini adalah pasien baru yang menjalani perawatan dan telah di diagnosis menderita penyakit telinga luar pada Klinik THT RSWS periode Januari sampai Desember 2012 yang terdapat dalam rekam medis pasien yang terdaftar sebagai diagnosis utama. Kriteria obyektif digunakan kelompok usia kami dibagi menjadi enam kelompok: 0-10 tahun, 11-20 tahun, 21-30 tahun, 31-40 tahun, 41-50 tahun dan > 50 tahun. Jenis kelamin digunakan sebagaimana ditunjukkan dalam status atau rekam medis pasien. Kriteria obyektif untuk gender adalah Pria dan Wanita. Dan untuk jenis penyakit telinga luar yang kita gunakan didasarkan pada diagnosis klinis dalam rekam medis.

\section{HASIL PENELITIAN}

Kami telah melakukan penelitian tentang karakteristik penyakit telinga luar selama periode Januari hingga Desember 2012 di RSWS. Dalam penelitian ini, kami ingin mengetahui kejadian penyakit dan karakteristik pasien berdasarkan jenis penyakit telinga eksternal, usia dan jenis 
kelamin. Jumlah pasien yang berkunjung untuk poli THT selama periode JanuariDesember 2012 adalah 10313 pasien. dari jumlah populasi tersebut, terdapat pasien baru yang menderita penyakit telinga luar sebanyak 984 pasien dan 673 pasien lama, jadi prevalensinya dalah $10,6 \%$.

Pada tabel 1 dapat dilihat kelompok usia terbesar yang menderita penyakit telinga luar adalah kelompok usia> 50 tahun yaitu 214 kasus $(21,7 \%)$ dari total 984 pasien diikuti oleh kelompok usia 2130 tahun sebanyak 175 kasus (17,8\%), sedangkan kelompok usia dengan persentase terkecil adalah usia 41-50 tahun $(12,5 \%)$. Untuk jenis kelamin, dapat dilihat pada grafik1 ditemukan bahwa lebih banyak pria menderita penyakit telinga luar 494 kasus $(50,2 \%)$ dibandingkan dengan wanita yang hanya 490 kasus $(49,8 \%)$.

Untuk jenis penyakit telinga luar yang paling banyak adalah pasien dengan otitis eksterna yaitu 408 orang $(43,2 \%)$ dari 944 pasien yang dapat dilihat pada tabel 2. Selanjutnya adalah pasien dengan serumen obturans 405 orang $(42,9 \%)$, benda asing 69 orang $(0,07 \%)$, kolesteatoma 18 orang $(0,02 \%)$, Fistula 16 orang $(0,02 \%)$, mikrotia 10 orang $(0$, $01 \%)$, Otomikosis 7 orang $(0,007 \%)$, atresia 6 orang $(0,006 \%)$, keratosis Obturans 5 orang $(0,005 \%)$, dan tidak ada pasien yang menderita Lop Ear's, Herpes zoster oticus, hematoma, pseudokista, dan perikondritis $(0 \%)$.

Karena penyakit telinga eksternal yang paling umum adalah otitis eksterna, sehingga kita mengeksplorasi karakteristik penyakit otitis eksterna sesuai dengan jenis penyakit, usia dan jenis kelamin yang paling menderita otitis eksterna. Dari analisis penelitian ini diperoleh hasil yaitu distribusi pasien sebanyak 408 kasus, kebanyakan kasus adalah kasus otitis eksterna difus yaitu 234 kasus $(57,4 \%)$ (grafik 2). Distribusi pasien dengan otitis eksterna berdasarkan kelompok usia dapat dilihat pada tabel 3 yaitu didapatkan sebagian besar kasus adalah usia> 50 tahun sebanyak 90 kasus $(22,1 \%)$ dan diikuti oleh kasus terkecil pada kelompok usia 010 tahun sebanyak 38 kasus $(9,8 \%)$. Distribusi pasien dengan otitis eksterna berdasarkan gender didapatkan 201 kasus berjenis kelamin laki-laki (49,3\%) dan 207 kasus $(50,7 \%)$ dengan jenis kelamin perempuan pada grafik 3 .

\section{PEMBAHASAN}

Penelitian ini ingin mengetahui kejadian penyakit telinga eksternal dan karakteristik pasien penyakit telinga eksternal berdasarkan jenis, usia dan jenis kelamin. Kelompok usia terbesar yang menderita penyakit telinga eksternal adalah kelompok 
usia> 50 tahun yaitu 214 kasus $(21,7 \%)$ dari total 984 pasien yang datang untuk pengobatan. Ini berbeda dengan penelitian sebelumnya pada tahun 2000 di Rumah Sakit Adam Malik di Medan, di mana hasil penelitian menunjukkan bahwa sebagian besar pasien berusia antara 21-30 tahun ${ }^{2}$. Untuk jenis kelamin, ditemukan bahwa laki-laki lebih menderita penyakit telinga luar 494 kasus $(50,2 \%)$ dibandingkan dengan perempuan yang hanya 490 kasus (49,8\%). Ditemukan hasil serupa dalam penelitian sebelumnya pada tahun $2000 \mathrm{di}$ Rumah Sakit Adam Malik, di mana rasio laki-laki dan perempuan adalah 1: $2,4^{2}$. Sebagian besar penyakit telinga luar yang dirawat di telinga hidung dan tenggorokan Klinik Rumah Sakit Umum Wahidin Sudirohusodo Makassar pada periode Januari-Desember 2012 adalah pasien dengan otitis eksterna yaitu 408 orang atau sekitar 43,2\% dari 944 pasien yang diobati dengan penyakit telinga eksternal. Acuteo titis eksterna (AOE) adalah radang telinga luar dan saluran telinga. Empat kategori otitis eksterna yang mencakup otitis eksterna lokal akut, otitis eksterna difus, otitis eksterna kronis, dan otitis eksterna maligna 9 . Ini cocok dengan data yang diperoleh oleh penelitian sebelumnya di berbagai rumah sakit, bahwa otitis eksterna sering ditemukan selain penyakit telinga lainnya. Berdasarkan data yang dikumpulkan di Rumah Sakit Adam Malik $^{2}$. Namun tidak seperti visi Survei Kesehatan dan pendengaran pada 1994 1996 yang dilaksanakan di tujuh (7) provinsi di Indonesia menunjukkan, penyebab paling umum morbiditas telinga luar adalah cerumen prop ${ }^{10}$. Kelompok usia terbesar yang menderita otitis eksterna di Rumah Sakit Umum Wahidin Sudirohusodo adalah usia> 50 tahun sebanyak 90 kasus $(22,1 \%)$. Ini berbeda dengan penelitian sebelumnya pada tahun 2000 di RS H.Adam Malik, dimana hasil penelitian menunjukkan bahwa sebagian besar pasien berusia antara 21-30 tahun. Distribusi pasien dengan otitis eksterna berdasarkan jenis kelamin diperoleh 201 kasus $(49,3 \%)$ dengan jenis kelamin lakilaki dan 207 kasus $(50,7 \%)$ dengan jenis kelamin perempuan. Ditemukan hasil serupa dalam penelitian sebelumnya pada tahun 2000 di RS H.Adam Malik, dimana rasio laki-laki dan perempuan adalah 1: 2,4, yaitu 19 pasien laki-laki dan 45 pasien perempuan $^{2}$.

\section{KESIMPULAN}

Setelah melakukan penelitian tentang karakteristik pasien penyakit telinga eksternal yang berobat di Rumah Sakit Umum Wahidin Sudirohusodo pada periode Januari hingga Desember 2012, dapat disimpulkan bahwa: Insidensi 
penyakit telinga luar selama periode Januari-Desember 2012 adalah 9,5\%. Distribusi penyakit telinga luar berdasarkan usia sebagian besar kelompok usia terbesar> 50 tahun sebanyak 214 kasus $(21,7 \%)$ dari total 984 pasien. Distribusi penyakit telinga luar karena seks bahwa laki-laki lebih menderita penyakit telinga luar $(50,2 \%)$ dibandingkan perempuan (49,8\%). Berdasarkan jenisnya, penyakit telinga luar kebanyakan ditemukan 408 kasus otitis eksterna $(43,2 \%)$ dari total 944 pasien yang diobati dengan penyakit telinga eksternal.

\section{DAFTAR PUSTAKA}

1. Departemen Kesehatan. 2011. Indikator Indonesia Sehat 2020. Departemen Kesehatan Indonesia

2. Abdullah F, 2003. Uji Banding Klinis Pemakaian Larutan Burruwi Saring Dengan Salep Ichthyol (Ichthammol) Pada Otitis Eksterna Akut. Fakultas Kedokteran Universitas Sumatra Utara, 1-38. Tesis

3. Pasetto, S., Polo, M.D., Taragona, E.S. 2014. External ear disease: a clinical update and radiologic view. European Clinicall Radiology

4. Nurbaiti, I., Efiaty, A.S. 2004. Buku Ajar Ilmu Kesehatan Telinga Hidung dan Tenggorok. Edisi 5. Balai Penerbit FKU1. Jakarta.

5. Departemen Kesehatan. 2010. Telinga Sehat Pendengaran Baik. Departemen Kesehatan Indonesia

6. Guest, JF., Greener MJ., Robinson AC, Smith AF. 2004. Impacted Cerumen : compotition, production, epidemiology and management. QJM.; 97(8):477-488

7. World Health Organization. 2010. Deafness and Hearing Impairment

8. Patrick,D, Georgirus.M, Marco,C. 2010. Ear Canal Cholesteatoma: Meta-analysis of Clinical Charateristics with Update on Classification Staging and Treatment. Otolaryngology and Head \& Neck Surgery. Volume 8. Issue 5. P 369-376

9. Murtaza, M., Patawai, P., Sien, M.M., et al. 2015. Acute Otitis Externa : Pathophysiology, Clinical Presentation, And Treatment. IOSRJDMS; 14(7):73-78

10. Kementrian Kesehatan. 2003. Rencana Strategi Nasional Penanggulangan Gangguan Pendengaran untuk Mencapai Sound Hearing 2030. Keputusan Menteri Kesehatan Republik Indonesia 


\section{DAFTAR TABEL}

Tabel 1 . Karateristik umur pada penderita penyakit telinga luar

\begin{tabular}{|lll|}
\hline Umur & Frekuensi & Presentase (\%) \\
\hline 0-10 tahun & 173 & 17.6 \\
11-20 tahun & 162 & 16.5 \\
21-30 tahun & 175 & 17.8 \\
31-40 tahun & 137 & 13.9 \\
41-50 tahun & 123 & 12.5 \\
$>$ 50 tahun & 214 & 21.7 \\
Total & 984 & 100.0 \\
\hline
\end{tabular}

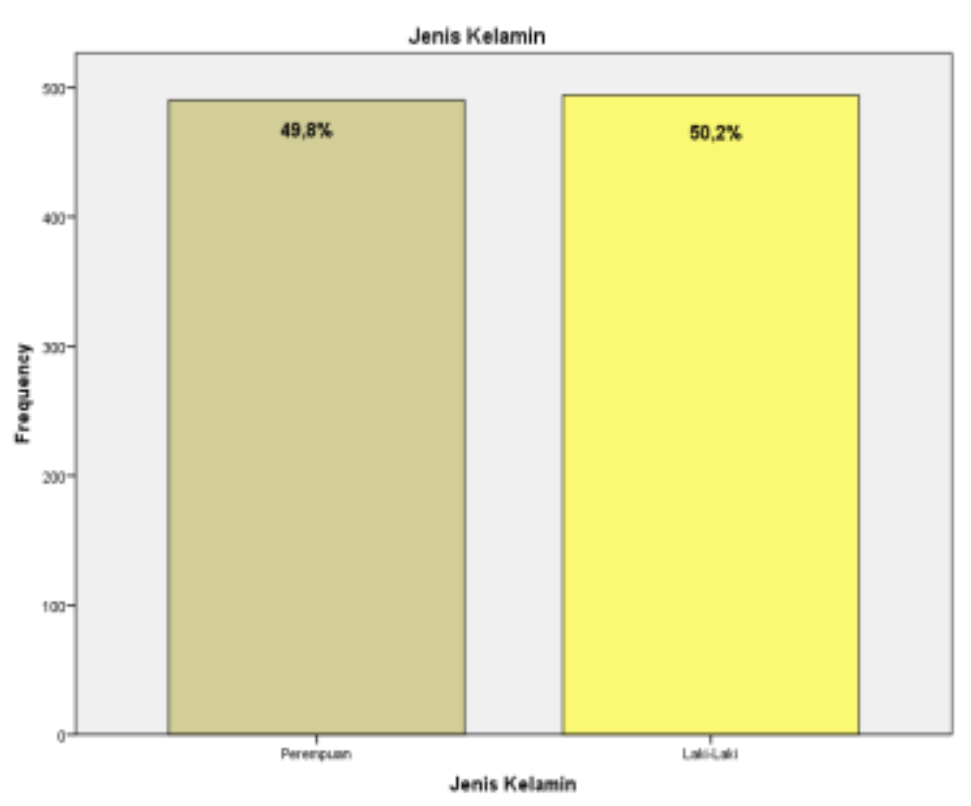

Grafik 1 . Karateristik jenis kelamin pada penderita penyakit telinga luar 
Tabel 2 . Karateristik jenis penyakit telinga luar

\begin{tabular}{|llll|}
\hline No & $\begin{array}{l}\text { Jenis Penyakit } \\
\text { Telinga Luar }\end{array}$ & Jumlah & $\begin{array}{l}\text { Presentase } \\
(\%)\end{array}$ \\
\hline $\mathbf{1}$ & Lop Ear's & 0 & 0 \\
$\mathbf{3}$ & Otitis Eksterna & 408 & 41,5 \\
$\mathbf{4}$ & Foreign Body & 69 & 7 \\
$\mathbf{5}$ & Microtia & 10 & 1,02 \\
$\mathbf{6}$ & Hematoma & 0 & 0 \\
$\mathbf{7}$ & Kolesteatoma & 18 & 1,83 \\
$\mathbf{8}$ & Serumen & 405 & 41,2 \\
$\mathbf{9}$ & Kerikondritis & 0 & 0 \\
$\mathbf{1 0}$ & Fistula Aurikuler & 16 & 0,5 \\
$\mathbf{1 1}$ & Herpes zooster oticus & 0 & 1,62 \\
$\mathbf{1 2}$ & Atresia Liang Telinga & 6 & 0 \\
$\mathbf{1 3}$ & Pseudokista & 0 & 0,6 \\
$\mathbf{1 4}$ & Otomikosis & 7 & 0 \\
$\mathbf{1 5}$ & Jaringan Granulasi & 23 & 0,7 \\
$\mathbf{1 6}$ & MAE & 13 & 2,33 \\
$\mathbf{1 7}$ & Laserasi MAE & 4 & 1,32 \\
\hline
\end{tabular}

Tabel 3 . Karateristik umur pada penyakit otitis eksterna

\begin{tabular}{|lll|}
\hline Umur & Frekuensi & Presentasi(\%) \\
\hline 0-10 tahun & 38 & 9.3 \\
11-20 tahun & 60 & 14.7 \\
21-30 tahun & 80 & 19.6 \\
31-40 tahun & 72 & 17.6 \\
$41-50$ tahun & 68 & 16.7 \\
$>50$ tahun & 90 & 22.1 \\
Total & 408 & 100.0 \\
\hline
\end{tabular}




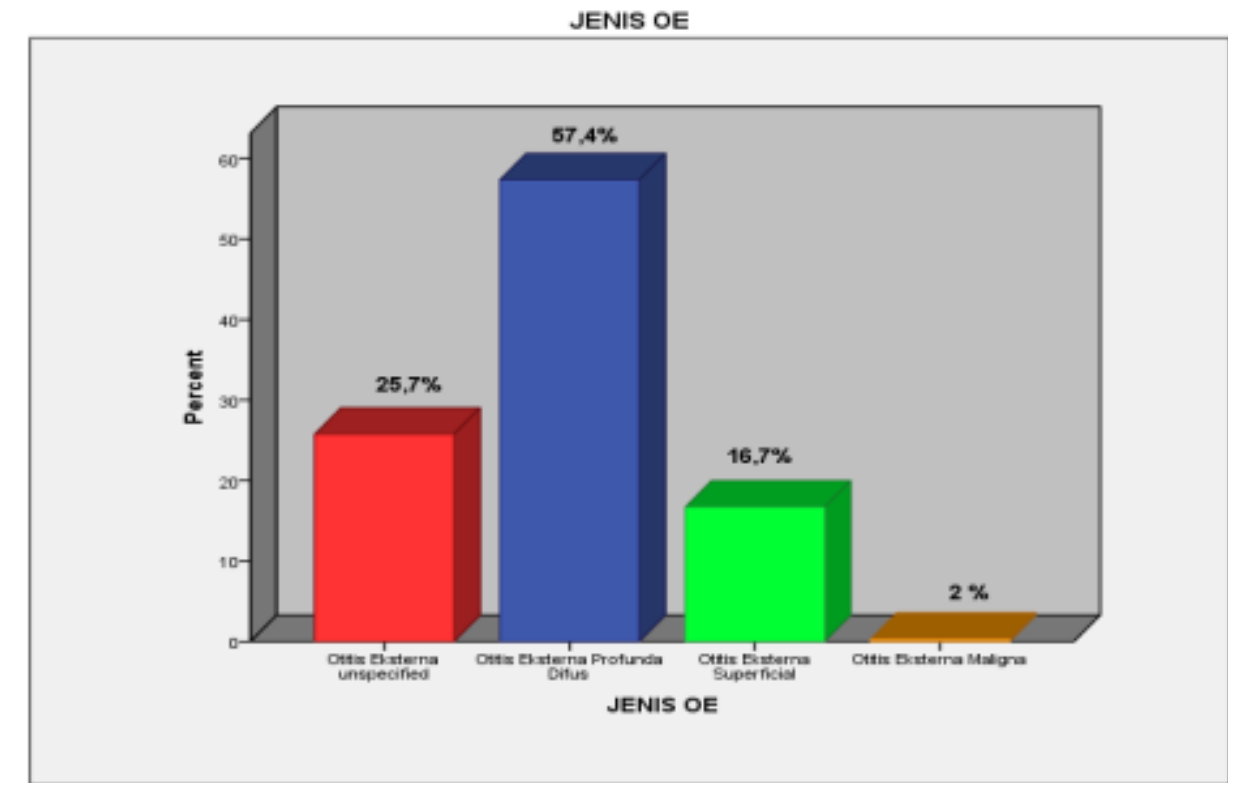

Grafik 2 . Karateristik jenis penyakit telinga luar

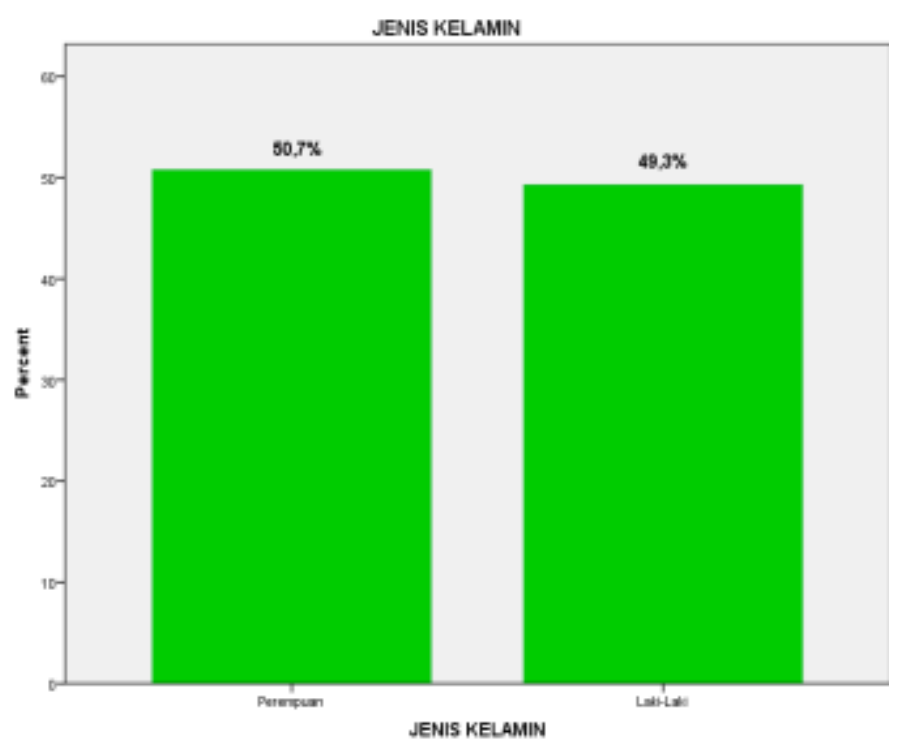

Grafik 3 . Karateristik jenis kelamin pada penyakit otitis eksterna 